\title{
TRAINING FOR MAKING KALANG BEVERAGE USING REED ROOTS FOR EMPOWERMENT OF PKK MOTHERS IN CAFE JLAMPRANG KELURAHAN KRAPYAK, PEKALONGAN
}

\author{
Dianka Wahyuningtias, Farah Levyta, Maria Pia Adiati \\ Bina Nusantara University, Indonesia \\ dwahyuningtias@binus.edu
}

\begin{abstract}
Pekalongan is one of the tourism destinations in Indonesia. Some cultures of Pekalongan can be developed and promoted especially in the culinary field. Pekalongan's special food and beverage offerings are one of the most potential products in attracting both local and foreign tourists. Not only because of its unique name but also because of the process of making and philosophy in a product that makes Pekalongan culinary specialties. But on its journey, Pekalongan cuisine has not been able to make the reason tourists come to visit Pekalongan. Akar alang-alang which is one of the special traditional drink ingredients of Pekalongan which is expected to be better known and available at Café Jlamprang, Krapyak Lor Village so that it can introduce Pekalongan's culinary culture more easily to the community and can embrace the young generation to get to know the Pekalongan culture. Because what is currently available are some drinks that use root-alang alang ingredients that can only be found in certain regions or in the form of instant drinks that can be found in souvenirs. In this study shows that Kalang has a unique taste and presentation. Then the production system can be done simply. Kalang has a high enough potential to be sold at Cafe Jlamprang, Krapyak Lor village so that if it is able to be developed and managed properly, efforts to preserve traditional drinks should be done not only by producers, but the government must also involve all elements of society.
\end{abstract}

Keywords: Kalang, Akar Alang-Alang, Pekalongan, Cafe Jlamprang Kelurahan Krapyak

\section{INTRODUCTION}

As it is known that there are many types of tourism in Indonesia and in the world. The types of tours that are known include nature tourism, cultural tourism, historical tourism, educational tourism, agricultural tourism, religious tourism, marine tourism, and culinary tourism. Of all these types of tours, culinary tourism has a high appeal for tourists. According to Long (2004: 20-21) culinary tourism is defined as the activities carried out deliberately to experience, explore, and participate in foodways (ways of eating) other people are not limited to consumption, but also involved in the preparation and presentation of food. Food in every region in Indonesia has its own characteristics that come from the spice concoction both for food and drinks. Food and beverages in each region are products that have important values in the tourism industry. So it can be concluded if culinary tourism is an activity of traveling to find food and drinks accompanied by a new atmosphere. Pekalongan City has a creative industry that has been able to promote the image of the city. The creative industry is the batik industry, through batik crafts, the City of Pekalongan has been designated a world creative city (Iglesias, 2014). Based on this, the City of Pekalongan has combined the batik industry with tourism activities through creative tourism. UNESCO (2006) explains that creative tourism is a journey that is directed to be able to engage and gain experience, by participatory learning in the arts, heritage, or special character of a tourist destination. Pekalongan City has sought to bring tourists through the development of Pesindon Batik Village, Kauman Batik Village, and Batik Museum, which in addition to selling works from the batik creative industry, also at the same time provide batik learning opportunities for tourists. Procurement of Pesindon Batik Village, Kauman Batik Village, and Batik Museum can be a tourist attraction that has a unique and cultural value that can be a targe (Damayanti \& Latifah, 2015) (Hesti Anagari S. A., 2011) (Jakarta) (Lutvianto, Ir. Usman Effendi, \& Dhita Morita Ikasari, 2014)t or a tourist destination in creative tourism in Pekalongan City. The tradition of the Pekalongan community is still close to the culture since long time ago which is full of salvation ceremonies complete with offerings in the form of food which has its own meaning in accordance with the ceremony held. Food for banquets (for guests) in the Pekalongan community is not much different from the daily menu, megono rice, tetelag, tauto, wedang alang-alang, and tahlil coffee. Thalil coffee drinks and wedang Alang-alang are common in gathering events (arisan) the existence of drinks that use alang -alang roots today in Pekalongan are usually served hot and added with some herbs such as ginger, lemongrass, turmeric. There are several instant beverage products that use alangalang roots which are used as souvenirs in the city of Pekalongan. If drinks from alang-alang roots are able to be well developed, they can be used as business opportunities as well as productive jobs. For example, by 
making use of Kalang then made into a typical Pekalongan drink and making the impression that anyone visiting especially those aiming to travel to Pekalongan is incomplete if it does not consume or buy Kalang drinks. This can be done with the cooperation of Binus Hotel Management and the Krapyak Lor village, namely by making an independent business to meet the desires of people who still intend to consume and create a good marketing system. So that Kalang drinks are easily accessible by anyone. So in addition to trying to preserve the existence of the drink is also expected to increase the attractiveness of domestic and foreign tourists to visit Pekalongan, especially Krapyak Lor village, so as to improve the regional economy, especially in the tourism sector. Then it also makes Pekalongan residents still have their regional identity, as a city that is developing but still preserving its culture, not forgetting it.

\section{The Purpose Of The Study}

1. PKK community has its own income and can develop according to new skills

2. Making new products from akar alang -alang

3. Introducing kalang as a distinctive drink cafe jlamprang

\section{Literature Review}

Determining shelf life by using the Accelerated Shelf Life Testing (ASLT) is done by speeding up the process of degradation or reaction in the experiment, namely raising the storage temperature on some level temperature above room temperature, thus speeding up analysis time shelf life. ASLT method used in determining the shelf-life reed roots extracts beverage using the parameter values of acidity $(\mathrm{pH})$ and color (brightness). reed roots extracts beverage stored for 35 days, at a temperature of $20^{\circ} \mathrm{C}, 30^{\circ} \mathrm{C}$ and $40^{\circ} \mathrm{C}$. From the Arrhenius model calculations with values obtained Ea (activation energy) for the parameters $\mathrm{pH}$ value of $9010.68 \mathrm{cal} / \mathrm{mol}$, while the color parameters (brightness) of $4110.16 \mathrm{cal} / \mathrm{mol}$, then the parameters used as the basis for determining the shelf life of reed roots extracts beverage is a parameter that has the smallest activation energy value, ie parameter color value (brightness). Shelf life of reed roots extracts beverage estimated for 44 days at $27^{\circ} \mathrm{C}$ and 41 days at $30^{\circ} \mathrm{C}$ (Hesti Anagari \& Wignyanto, 2011. The tradition of increasing sales of Sari Alangalang Pesona beverage products should have been maintained and even developed by UKM R. Rovit. Until now there has never been a study of customer satisfaction with this product, therefore in this study an analysis of customer satisfaction using the QFD method. The purpose of this study is to analyze the level of customer satisfaction with Sari Alang-alang Pesona products using the QFD method, and determine the company's strategy in responding to customer expectations. The results of this study indicate that the average customer satisfaction of Sari Alang-alang Pesona products is 4,115 (satisfying). The highest priority order in technical features is the state of the machine with a value of $14,723 \%$, while for the highest priority order in applied technology is the application of ISO 22000 food safety management system which is worth $24,452 \%$. Besides that in the manufacturing process, the highest priority was found in HACCP preparation with a value of $19.454 \%$. Of the three solutions offered by looking at the highest priority value, the priority order of the solutions offered is first applied technology, second place is manufacturing process and third place is technical characteristic. The proposed SME strategy in responding to customer expectations is to study and prepare the requirements for implementing an ISO 22000 food safety management system in accordance with the guidelines issued by the authorized certification body. Besides that, SMEs are also expected to be able to prepare everything related to the preparation of HACCP. SMEs are also expected to maintain the performance and condition of machinery and production equipment, so that products are produced that meet customer expectations and customer confidence is maintained (Lutvianto, N., Ir. Usman Effendi, M., \& Dhita Morita Ikasari, S. M., 2014). Imperata grass is widely used as raw material for herbal and medicinal industries, especially its rhizomen. Rhizome quality of Imperata is influenced by various factors, one of which is the growth environment. The purpose of this study was to determine differences in glucose, carotenoid and biomass of Imperata plants that grow in shaded areas in Blora Regency and Semarang Regency. Plant samples were taken from locations in Blora and Semarang districts with 10 replications. The method of measuring glucose and carotenoid levels is carried out using a UV-spectrophotometer. Biomass measurements of Imperata plants include fresh weight and dry weight of the plant. Data analysis used Independent T - Test at 95\% confidence level with SPSS software version 16. Carotenoid and glucose levels in Imperata grass rhizome originating from Blora Regency were 
$0.8817 \mathrm{ppm}$ and $2.871 \mathrm{ppm}$ and biomass (wet weight 10.98 gram and dry weight of 2.81 grams in Semarang Carotenoid and glucose levels in Imperata grass rhizome originating from Semarang Regency were $0.7966 \mathrm{ppm}$ and $2.0686 \mathrm{ppm}$. The results showed that glucose and carotenoid levels of Imperata plants from the Regency Blora and Semarang did not differ significantly but the Imperata biomass was significantly different (Martha, Prihastanti, \& Haryanti2, 2016)

\section{Benefits of Alang-Alang Root}

According to (W., 2008)the efficacy of alang-alang root is very much as a remedy for various health problems, such as: kidney stones, kidney infections, urinary stones, gallstones, urination is not smooth or continuous, urine contains blood, prostate, vaginal discharge, whooping cough, coughing up blood, nosebleeds, bleeding in women, fever, measles, inflammation of the liver, hepatitis, high blood pressure, weakened nerves, asthma, pneumonia, coronary heart disease, digestive disorders, diarrhea, etc. other.

Benefits of the compounds contained in the roots of the reeds (Adina, 2012):

a. In the Imperata roots contained imperanene which turned out to have the effect of inhibiting the aggregation of platelets (blood clotting cells) according to the results of research by experts from the University in Japan. The effect of inhibiting this aggregation is the same as the effect caused by acetosal (acetyl salicylic acid) which is used to prevent blood clots in patients with heart attack.

b. Cylindol A contained in Imperata roots has the effect of inhibiting the enzyme 5- lipoxygenase. With the inhibition of 5-lipoxygenase, the formation of prostaglandins that cause pain or pain in the muscles can be blocked. Other ingredients contained, namely Cylendrene has the activity of inhibiting the contraction of blood vessels in smooth muscle so that blood circulation remains smooth.

c. Graminone B inhibits the narrowing of the aortic arteries (the largest blood vessels).

d. From the test results it turns out that this plant which is also called thatch has a pharmacological effect or in other words this plant has the properties: antipyretic (reduce heat), hemostatic (to stop bleeding), eliminate thirst, and diuretics (urinary decay).

\section{Wedang Alang-Alang}

Wedang alang-alang is the wealth of the Pekalongan community not only having cultural values but also economic values. This drink is always produced by the Pekalongan community with a fairly high level of diversity between one place of manufacture and another in the Pekalongan region. This diversity occurs in all aspects, including raw materials, production methods, packaging, taste, color, and aroma. The technological innovation standardization of making Wedang Alang-Alang does not require special requirements, as long as it follows the Standard Operating Procedure (SPO) that has been prepared, which starts from the cleaning, manufacturing, to presentation process. The advantages of this innovation are the quality of products and market competitiveness / selling value will be higher and the sustainability of the business processors will be more secure, given the type of alang-alang reed drink has been declared as a typical beverage for tourist guests to the Pekalongan region. Alang-alang root as raw material for making wedang alang-alang is selected which has good quality. The innovation that will be made is how to make this reed alang-alang can also be enjoyed by using ice cubes with the addition of young coconut. Then the alang-alang root is made of sympel syrup so that it can be made into a mixture of coconut ice or a mixture of fruit ice that can add to the diversity of drinks by using alang-alang roots.

The composition of Kalang to make 1 liter of alang -alang sugar syrup is:

$1 \mathrm{~kg}$ of alang-alang roots

1 liter of water

$1 \mathrm{~kg}$ of sugar

4 young coconuts

Ice Cube

The process of making Kalang is:

1). Reception and sorting of Alang-alang roots 
2). Washing

3). Weighing ingredients

4). Boiling water and reeds

5). Filtering

6). Boiling alang alang water with sugar

7). Cooling down

8). Mixing with coconut

To get a good quality Kalang the manufacturing process follows the SPO that has been prepared, namely:

1. Alang-alang roots is washed / cleaned of impurities.

2. Parts that are not properly thrown away

3. Alang-alang are reduced in size, then press

4. All ingredients are weighed / measured according to the formula.

5. Boil water until the temperature reaches 95-1050C.

6 . Add all ingredients except sugar. The pan must be closed.

7. Let the stew for 30 minutes.

8. Filter

9. Enter the sugar. Let the sugar dissolve for 5-10 minutes.

10. Before being stored sugar water is allowed to stand until cool

11. Prepare young coconut

12. Put coconut water and young coconut meat in a glass

13. Mix with reeds sugar water

14. Mixing with coconut, done if you really want to be served (because young coconut water cannot be stored for long)

The advantages of this innovation are product quality and market competitiveness / selling value will be higher and the business continuity of the processors will be more secure, considering the type of beverage using reed roots has been designated as a typical Pekalongan beverage.

\section{Research Methodology}

The implementation to be discussed is a social and dynamic problem. Therefore, researchers chose to use qualitative research methods to determine how to search, collect, process and analyze the research data. Research is a qualitative research, this research can be used to understand social interactions, for example by conducting in-depth interviews so that clear patterns will be found, namely in-depth research. An understanding of qualitative research proposed by (Komariah, 2011)). According to Satori \& Komariah the notion of qualitative research is: Qualitative research is research that emphasizes or focuses on quality or the most important thing from the nature of an item or service. The most important thing of a product or service is an event, phenomenon or social phenomenon that has the meaning behind the event that can be used as valuable learning for a development of theoretical concepts. Meanwhile according to Bogdan and Taylor (1975) cited (Moleong, 2017)argues that qualitative methodology as a procedure or research method that produces various kinds of descriptive data in the form of written or oral words from people and observable behavior. Furthermore, explained by David Williams (1995) as quoted by Moleong (2017: 5) explains that qualitative research is the collection of data in a natural setting, using natural methods or methods, and carried out by a person or researcher who is naturally interested. The researcher aims to find out the uniqueness of the traditional drinks that characterize Pekalongan, as well as the benefits of the Kalang drink, and to know what if Kalang can be used as a business, so that in addition to increasing income and increasing the economic development of the local community it is also able to make one of the preservation efforts of traditional drinks typical Pekalongan. The implementation of community service activities in Wangun Hamlet, Pekalongan, the implementation team shared activities in terms of training and mentoring for PKK community The approach taken in this PKM assistance is through participatory approach method. Which is divided into several stages, namely:

1. Survey and data collection and analysis of activities needed to find information about activities related to making Akar alang-alang drink, 
2. Trial of making drinks that usually use akar alang-alang

3. Training on making kalang, including

3.1 Discussion of the creation of akar alang-alang drink

3.2 Training on the manufacture of kalang-based foods including how to choose akar alang-alang, read recipes, weigh ingredients, process of making

3.3 Assistance in the process of making kalang, and presenting, monitoring activities, and coaching groups to monitor the continuity of drink making business.

\section{KALANG Making Process}

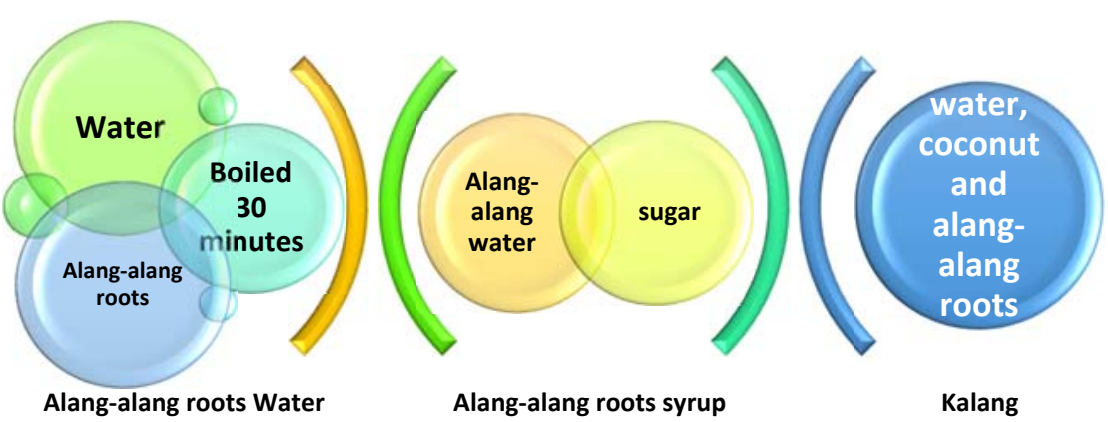

The tools used in this study were Alang-alang roots, strainer, big bowl, knife, stock pot, leadle, gas stoves.

\section{Result and discussion}

The expected targets can be achieved from carrying out the business of commercialization and product socialization of Kalang (Kelapa Alang-Alang), namely:

Increasing Creativity and Entrepreneurship Spirit Community Krapyak Lor Districk

This activity is an appropriate means to enhance the entrepreneurial spirit of the community through independent business. Creativity can be honed from exploring ideas that are not thought of by most people and from various kinds of innovations carried out to follow the development of consumer tastes without reducing the benefits and values that can be obtained by consumers as optimal as possible.

Generate Operating Profit

The business development of Kalang (Kelapa Alang-Alang) is expected to produce optimum profit. Profits can be used again as capital to develop the business further. Through good capital turnover, it is expected to encourage business development so that the business can be run sustainably.

Opening New Job Opportunities While Raising the Community's Economy

One of the expected long-term outcomes is to open new jobs for the community, especially those who live around the Krapyak Lor sub-district so that they can directly or indirectly improve the 
welfare of the community in the form of income as a workforce. This target can also be a practice of higher education.

Introducing Pekalongan Traditional Products to the Community at Large

Kalang products (Alang-Alang Coconut) as an alternative to Pekalongan's special health drink can be known more widely by the community especially around the Krapyak Lor district office. This has become one of the efforts to preserve regional special products. This effort can also increase the economic value of Root Alang-alang to improve the position of traditional products typical of the region so that it is no less competitive with beverage products originating from abroad or instant drinks.

Making Innovations Against Pekalongan Distinctive Products Innovation is one thing that is important so that Kalang products (Coconut Alang-Alang) can still be accepted by the community even though consumer tastes continue to change. This innovation includes the development of products both in terms of taste, color and composition of ingredients, even through the way of presentation mixed with young coconut, fruit ice, sweet tea

\section{Planned Strategy in the development of kalang production}

After starting the process of making Kalang (Alang-Alang Coconut) so that it produces a good recipe, the next stage is the production preparation stage which includes the purchase of production equipment and equipment. Furthermore, after all production equipment is available, purchasing raw materials is made. The next stage is the production process of Kalang (Alang-Alang Coconut). The production of Kalang (Alang-Alang Coconut) in the initial stage is to find out market responses through a product launching program. The product launching is intended to introduce this product to consumers, especially in the segmentation of the Krapyak Lor village community. The second production process is a production that is intended to throw Kalang products (Kelapa Alang-Alang) at Jlamprang café.

The third stage is the business development stage of Kalang (Kelapa Alang-Alang). This long-term business plan is a testament to the commitment to preserve "Kalang" as an invaluable heritage of Pekalongan culture. Another goal of this long-term effort is to strengthen the bargaining position of "Kalang" in the Indonesian beverage market as a traditional beverage that is rich in properties. The long-term plan for this business is to change the marketing system by opening an outlet branch into a franchise system. The purpose of opening a "Kalang" franchise business is to open as wide opportunities as possible to people who are interested in entrepreneurship through the "Kalang" business. With this system, the "Kalang" business will quickly develop both in local and national markets. If the administrative, financial and logistical systems are stable and reliable, a franchise system will be put in place.

\section{Conclusion and Suggestion}

\section{Conclusion}

From the activities of the Partnership for the development of kalang processed products in the hamlet of Krapyak Lor, the following results have been obtained:

1. Increased knowledge and skills through training and mentoring activities for the manufacture of processed kalang products such as traditional drink for PKK community

2. Increased knowledge and skills in diversification of kalang processed products through training and mentoring activities for making traditional drinks

3. The growth of the spirit of togetherness and sustainability of the program by involving the village government, related agencies and private parties in the Krapyak Lor greatly helped the development of kalang-based products and the local economic potential in Krapyak Lor.

Suggestion

Based on the discussion and conclusions above, we present several suggestions, including:

1. Obstacles in the form of enthusiasm to initiate entrepreneurship are still very low, so that people need to be motivated and successful examples for the development of kalang-based products

2. There needs to be support for advanced programs, to increase the enthusiasm, skills and marketing ability of the women members of the Krapyak Lor hamlet PKK 


\section{References}

Damayanti, M., \& Latifah. (2015). STRATEGI KOTA PEKALONGAN DALAM PENGEMBANGAN WISATA KREATIF BERBASIS INDUSTRI BATIK. Jurnal Pengembangan Kota.

Hesti Anagari, S. A. (2011). PENENTUAN UMUR SIMPAN MINUMAN FUNGSIONAL SARI AKAR ALANG - ALANG DENGAN METODE ACCELERATED SHELF LIFE TESTING (ASLT) (Studi Kasus di UKM "R.ROVIT" Batu - Malang). Agrointek.

Komariah, D. S. (2011). Metodologi Penelitian Kualitatif. Alfabet.

Lutvianto, N., Ir. Usman Effendi, M., \& Dhita Morita Ikasari, S. M. (2014). CUSTOMER SATISFACTION ANALYSIS OF PRODUCT EXTRACT ALANG-ALANG PESONA USING QUALITY FUNCTION DEPLOYMENT (QFD) METHOD (Case Study at UKM R. ROVIT Batu Tourism Town).

Lutvianto, N., Ir. Usman Effendi, M., \& Dhita Morita Ikasari, S. M. (2014). PENENTUAN UMUR SIMPAN MINUMAN FUNGSIONAL SARI AKAR ALANG - ALANG DENGAN METODE ACCELERATED SHELF LIFE TESTING (ASLT) (Studi Kasus di UKM "R.ROVIT" Batu - Malang.

Martha, D. A., Prihastanti, E., \& Haryanti2, S. (2016). Perbedaan Kadar Glukosa, Karotenoid dan Biomassa Alang-Alang (Imperata cylindrica L. Beauv) yang Tumbuh di Daerah Ternaungi di Kec. Kunduran Blora dan Ungaran Timur Semarang. Buletin Anatomi dan Fisiologi.

Moleong, L. J. (2017). Metode Penelitian Kualitatif. Bandung: PT. Remaja Rosdakarya Offset.

W., P. H. (2008). Ramuan Lengkap Herbal Taklukkan Penyakit. Niaga Swadaya, 2008. 